\title{
Fluorescence detection of single-nucleotide polymorphisms using a thymidine-based molecular beacon
}

\author{
Chi-Wei Liu ${ }^{a}$, Yang-Wei Lin ${ }^{a}$, Chih-Ching Huang ${ }^{b}$, Huan-Tsung Changa,* \\ a Department of Chemistry, National Taiwan University, 1, Section 4, Roosevelt Road, Taipei 106, Taiwan \\ ${ }^{\mathrm{b}}$ Institute of Bioscience and Biotechnology, National Taiwan Ocean University, 2, Beining Road, Jhongiheng District, Keelung 202, Taiwan
}

\section{A R T I C L E I N F O}

\section{Article history:}

Received 30 September 2008

Received in revised form

28 December 2008

Accepted 5 January 2009

Available online 14 January 2009

\section{Keywords:}

Molecular beacon

Single-nucleotide polymorphisms (SNPs)

Thymidine

Sensor

Mercury

Hereditary tyrosinemia type I

\begin{abstract}
A B S T R A C T
We have developed a universal molecular beacon $\left(\mathrm{T}_{7}-\mathrm{MB}-\mathrm{T}_{7}\right)$ for the detection of single-nucleotide polymorphisms (SNPs). The beacon, which contains a 19-mer loop and a stem comprising a pair of seven thymidine $(\mathrm{T})$ bases, forms double-stranded structures with target DNA molecules, leading to increases in the fluorescence of ethidium bromide $(\mathrm{EthBr})$ as a result of intercalation. The interactions of the beacon with perfectly matched $\left(\mathrm{DNA}_{\mathrm{pm}}\right)$ and single-base mismatched $\left(\mathrm{DNA}_{\mathrm{mm}}\right)$ DNA strands are stronger and weaker, respectively, than those with $\mathrm{Hg}^{2+}$ ions. As a result, the fluorescence of a solution containing $\mathrm{T}_{7}-\mathrm{MB}-\mathrm{T}_{7}, \mathrm{DNA}_{\mathrm{pm}}$, EthBr, and $\mathrm{Hg}^{2+}$ is higher than that of a corresponding solution containing $\mathrm{T}_{7}-\mathrm{MB}-$ $\mathrm{T}_{7}, \mathrm{DNA}_{\mathrm{mm}}$, EthBr, and $\mathrm{Hg}^{2+}$, because the former has a greater number of intercalation sites for EthBr. Under the optimal conditions ( $100 \mathrm{nM} \mathrm{T}_{7}-\mathrm{MB}^{-} \mathrm{T}_{7}, 20 \mathrm{mM} \mathrm{NaCl}, 5.0 \mu \mathrm{M} \mathrm{Hg}^{2+}$, and $300 \mathrm{nM}$ EthBr in $5.0 \mathrm{mM}$ Tris- $\mathrm{HCl}$ solution, $\mathrm{pH} 7.4$ ), the plot of the fluorescence intensity against the concentration of $\mathrm{DNA}_{\mathrm{pm}}$ was linear over the range $5.0-100 \mathrm{nM}\left(R^{2}=0.98\right)$. A similar probe, $\mathrm{T}_{7}-\mathrm{MB}_{\mathrm{t}}-\mathrm{T}_{7}$, is sensitive and selective for the detection of a gene associated with hereditary tyrosinemia type I. Relative to conventional MBs, our new probe offers the advantages of higher selectivity toward DNA, less nonspecific binding toward single-stranded-DNA-binding protein, greater resistance to nuclease digestion, and low cost; therefore, we suspect that this system holds great potential for practical studies of SNPs.
\end{abstract}

(c) 2009 Elsevier B.V. All rights reserved.

\section{Introduction}

Single-nucleotide polymorphisms (SNPs), the most common form of variation in the human genome, are important markers for the diagnosis of disease, for studies of the genome, and for the synthesis of new medicines (Gray et al., 2000). The last few years have witnessed significant progress in the development of optical and electrochemical techniques for the detection of DNA molecules that have sequences differing in (or missing) a single base, employing, for example, molecular beacons (MBs) (Tyagi and Kramer, 1996), DNA-modified nanoparticles (Storhoff et al., 2004; Nam et al., 2004), conjugated polymers (Gaylord et al., 2002; Liu and Bazan, 2004), DNA-specific redox indicators and conjugated mediators (Kelley et al., 1999; Drummond et al., 2003), and DNA-conjugated enzymes (Li et al., 2005; Kolpashchikov, 2008). Although they are sensitive and specific, many of these systems have features that limit their practical use, such as tedious bioconjugation and labeling processes, the need for expensive reagents and biomolecules (e.g., enzymes and fluorescent dye-labeled DNA molecules), and

\footnotetext{
* Corresponding author. Tel.: +11 8862 33661171; fax: +11 886233661171 .

E-mail address: changht@ntu.edu.tw (H.-T. Chang).
}

the need for tight control over the experimental conditions (e.g., temperature).

Fluorescence spectroscopy using MBs that form stem-and-loop structures to recognize targeted DNA molecules is particularly interesting in the study of SNPs, mainly because they offer the advantages of simplicity and sensitivity. In a common MB, the loop contains a probe sequence that is complementary to a target sequence, and the termini of the stem are modified with a donor (fluorophore) and an acceptor (quencher), respectively. MBs act as fluorescence resonance energy transfer (FRET)-based switches that are normally in the closed or "fluorescence off" state, but switch to the open or "fluorescence on" state in the presence of target (complimentary) DNA strands.

When MBs are used for the detection of SNPs, problems occur that are associated with their nonspecific binding to singlestranded-DNA-binding protein (SSB) and endogenous nuclease degradation, leading to false-positive signals and, hence, their limited applicability in complex biological samples (Leonetti et al., 1991; Fisher et al., 1993). Another major drawback of MBs is that they are usually expensive because the two ends of the stem and the sequence of MBs must be modified with signal generators and nuclease-resistant backbone chemistries, respectively (Tsourkas et al., 2002; Kuhn et al., 2002, Kim et al., 2007). We have previ-

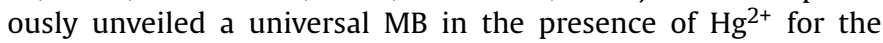


detection of SNPs based on $\mathrm{Hg}^{2+}$-DNA complexes inducing a conformational change in the MB. The specificity of SNPs was enhanced 10 -fold or more toward normal MBs and problems associated with interferences of SSB and endogenous nuclease degradation were minimized (Lin et al., 2008). However, expensive fluorescent MBs were employed.

In this paper, we present a fluorescence assay-employing a thymidine-based $\mathrm{MB}\left(\mathrm{T}_{7}-\mathrm{MB}-\mathrm{T}_{7}\right)$ in the presence of $\mathrm{Hg}^{2+}$ and ethidium bromide $(\mathrm{EthBr})$-for the detection of SNPs. The $\mathrm{T}_{7}-\mathrm{MB}-\mathrm{T}_{7}$ contains a stem comprising a pair of 7-mer T bases, which interact with $\mathrm{Hg}^{2+}$ ions, and a loop of 19-mer DNA bases, which recognize the targeted DNA. Because of the $\mathrm{T}-\mathrm{Hg}^{2+}-\mathrm{T}$ interactions (Ono and Togashi, 2004; Liu et al., 2008), the $\mathrm{Hg}^{2+}$-DNA complexes in the hairpin structure are more resistant to nuclease degradation and less likely to form complexes with SSB. We investigated the roles that the $\mathrm{pH}$, the nature of the dye, and the concentrations of $\mathrm{Hg}^{2+}$ and $\mathrm{NaCl}$ in the probe solutions play in determining the sensitivity and selectivity of the $\mathrm{T}_{7}-\mathrm{MB}-\mathrm{T}_{7}$ probe toward perfectly matched $\left(\mathrm{DNA}_{\mathrm{pm}}\right)$ and single-base mismatched $\left(\mathrm{DNA}_{\mathrm{mm}}\right)$ DNA strands. In addition, we evaluated the performance of several different DNA probes to confirm the advantageous features of the $T_{7}-M B-T_{7}$ probe for SNPs studies.

\section{Experimental}

\subsection{Chemicals}

Tris(hydroxymethyl)aminomethane (Tris), mercury chloride $\left(\mathrm{HgCl}_{2}\right)$, magnesium chloride $\left(\mathrm{MgCl}_{2}\right)$, and deoxyribonuclease I (DNase I) were purchased from Aldrich (Milwaukee, WI, USA). The MBs and DNA samples (see Table 1 for sequences) were purchased from Integrated DNA Technology, Inc. (Coralville, IA, USA); SSB was purchased from Promega (Madison, WI, USA). EthBr, YOYO-3, TOTO3 , and OliGreen were obtained from Molecular Probes (Portland, OR). Milli-Q ultrapure water was used in all experiments.

\subsection{Analysis of samples}

Aliquots $(350.0 \mu \mathrm{L})$ of $5.0 \mathrm{mM}$ Tris- $\mathrm{HCl}$ buffer $(\mathrm{pH} 7.4)$ containing $\mathrm{NaCl}(0-100.0 \mathrm{mM})$ and one of the tested MBs (100.0 nM) were maintained at ambient temperature for $5 \mathrm{~min}$. Aliquots $(50.0 \mu \mathrm{L})$ of the target DNA $(1.0 \mu \mathrm{M})$ were added separately to each of the probe solutions, which were then incubated for $1 \mathrm{~h}$. The final ratio of the concentrations of the MBs to the targeted DNA was $1: 1$. An aliquot $(50 \mu \mathrm{L})$ of $\mathrm{Hg}^{2+}(0-10.0 \mu \mathrm{M})$ was added to each solution, which was incubated for $1 \mathrm{~h}$ and then $\operatorname{EthBr}(0.1-5.0 \mu \mathrm{M})$ or another dye $(1.0 \mu \mathrm{M})$ was added. The mixtures were further equilibrated for 10 min prior to fluorescence measurements (Cary Eclipse; Varian, CA, USA).

To evaluate the degree of nonspecific binding of the MB probes to SSB, 5.0 mM Tris-HCl buffer ( $\mathrm{pH} 7.4,350.0 \mu \mathrm{L}$ ) solutions containing $\mathrm{NaCl}(20.0 \mathrm{mM}), \mathrm{SSB}(100.0 \mathrm{nM})$, one of the MBs $(100.0 \mathrm{nM})$, and the targeted DNA ( 0 and $100.0 \mathrm{nM}$ ) were maintained at ambient temperature for $60 \mathrm{~min}$. An aliquot $(50 \mu \mathrm{L})$ of $\mathrm{Hg}^{2+}(5.0 \mu \mathrm{M})$ was added to each solution, which was then incubated for 60 min before $\operatorname{EthBr}(0.3 \mu \mathrm{M})$ was added. The mixtures were further equilibrated for $10 \mathrm{~min}$ prior to fluorescence measurement.

To evaluate the resistance of the MBs toward endogenous nuclease degradation, aliquots $(400.0 \mu \mathrm{L})$ of $5.0 \mathrm{mM}$ Tris- $\mathrm{HCl}$ buffer $(\mathrm{pH}$ 7.4) containing $\mathrm{NaCl}(20.0 \mathrm{mM}), \mathrm{MgCl}_{2}(5.0 \mathrm{mM})$, one of the MBs (100.0 nM), $\mathrm{Hg}^{2+}(5.0 \mu \mathrm{M})$, and $\operatorname{Eth} \operatorname{Br}(0.3 \mu \mathrm{M})$ were maintained at ambient temperature for $1 \mathrm{~h}$ and then an aliquot $(50.0 \mu \mathrm{L})$ of DNase I (final concentration: $2.5 \mu \mathrm{g} / \mathrm{mL}$ ) was added to each solution. The mixtures were then subjected to fluorescence measurements while they were equilibrated for certain periods of time, as indicated in
Table 1

DNA sequences of MBs and Target DNA.

\begin{tabular}{|c|c|}
\hline name & sequence $\left(5^{\prime}-3^{\prime}\right)$ \\
\hline $\mathrm{T}_{6}-\mathrm{MB}-\mathrm{T}_{6}$ & TTTTTTTCTAAATCACTATGGTCGCTTTTTT \\
\hline $\mathrm{T}_{7}-\mathrm{MB}-\mathrm{T}_{7}$ & 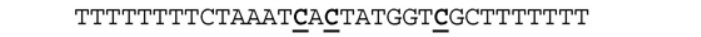 \\
\hline $\mathrm{T}_{8}-\mathrm{MB}-\mathrm{T}_{8}$ & TTTTTTTTTCTAAATCACيTATGGTCGCTTTTTTTT \\
\hline $\mathrm{MB}_{\mathrm{C} 1}$ & ACCTAGCTCTAAATCACTATGGTCGCGCTAGGT \\
\hline $\mathrm{MB}_{\mathrm{C} 2}$ & FAM-ACCTAGCTCTAAATCACTATGGTCGCGCTAGGT-DABCYL \\
\hline $\mathrm{MB}_{\mathrm{C} 3}$ & FAM-TTTTTTTTCTAAATCACTAATGTCGCAAAAAAA-DABCYL \\
\hline $\mathrm{MB}_{\mathrm{C} 4}$ & FAM-GGGGGGGTCTAAATCACTATGGTCGCCCCCCCC-DABCYL \\
\hline $\mathrm{MB}_{\mathrm{C} 5}$ & FAM-ACTTAGTTCTAAATCACTATGGTCGCACTAAGT-DABCYL \\
\hline $\mathrm{MB}_{\mathrm{C} 6}$ & FAM-GCCGAGCTCTAAATCACTATGGTCGCGCTCGGC-DABCYL \\
\hline $\mathrm{DNA}_{\mathrm{pm} 1}$ & GCGACCATAGTGATTTAGA \\
\hline $\mathrm{DNA}_{\mathrm{mm} 1}$ & GCGACCATAATGATTTAGA \\
\hline $\mathrm{DNA}_{\mathrm{mm} 2}$ & GCGACCATACTTATTTAGA \\
\hline $\mathrm{DNA}_{\mathrm{mm} 3}$ & GCGACCATATTGATTTAGA \\
\hline $\mathrm{DNA}_{\mathrm{mm} 4}$ & GCA-ACCATAGTGATTTAGA \\
\hline $\mathrm{DNA}_{\mathrm{mm} 5}$ & GCIIACCATAGTGATTTAGA \\
\hline $\mathrm{DNA}_{\mathrm{mm} 6}$ & GCÉACCATAGTGATTTAGA \\
\hline $\mathrm{DNA}_{\mathrm{mm} 7}$ & GCGACCATAGTA-ATTTAGA \\
\hline $\mathrm{DNA}_{\mathrm{mm} 8}$ & GCGACCATAGTIATTTAGA \\
\hline $\mathrm{DNA}_{\mathrm{mm} 9}$ & GCGACCATAGT $\underline{C A T T T A G A}$ \\
\hline $\mathrm{T}_{7}-\mathrm{MB}_{1}-\mathrm{T}_{7}$ & TTTTTTTTCTAAATTACTATTGTTGTTTTTTTT \\
\hline $\mathrm{DNA}_{\mathrm{pm} 2}$ & ACAACAATAGTAATTTAGA \\
\hline $\mathrm{DNA}_{\mathrm{mm} 10}$ & ACAACAATAATAATTTAGA \\
\hline $\mathrm{T}_{7}-\mathrm{MB}_{2}-\mathrm{T}_{7}$ & TTTTTTTCCTAACCCACTACGGTCGCTTTTTTT \\
\hline $\mathrm{DNA}_{\mathrm{pm} 3}$ & GCGACCGTAGTGGGTTAGG \\
\hline $\mathrm{DNA}_{\mathrm{mm} 11}$ & GCGACCGTA \\
\hline $\mathrm{T}_{7}-\mathrm{MB}_{\mathrm{t}}-\mathrm{T}_{7}$ & TTTTTTTCCAGATACTCACCGGTTTTTTT \\
\hline $\mathrm{DNA}_{\text {pmt }}$ & CCGGTGAGTATCTGG \\
\hline $\mathrm{DNA}_{m m t}$ & CCGGTGAATATCTGG \\
\hline
\end{tabular}

Section 3. Finally, the target DNA (final concentration $100.0 \mathrm{nM}$ ) was added to each mixture and its fluorescence was continually recorded.

\section{Results and discussion}

\subsection{Sensing strategy}

Scheme 1 displays the sensing strategy of the $\mathrm{T}_{7}-\mathrm{MB}-\mathrm{T}_{7}$ probe toward target DNA molecules. Because the $\mathrm{T}_{7}-\mathrm{MB}-\mathrm{T}_{7}$ probe possesses seven pairs of $\mathrm{T}$ bases, it exists in a random coiled structure, but forms folded structures in the presence of $\mathrm{Hg}^{2+}$ ions through $\mathrm{T}-\mathrm{Hg}^{2+}-\mathrm{T}$ binding. Under optimal conditions, the interactions of $\mathrm{T}_{7}-\mathrm{MB}-\mathrm{T}_{7}$ with $\mathrm{DNA}_{\mathrm{pm}}$ and $\mathrm{DNA}_{\mathrm{mm}}$ are stronger and weaker, respectively, than those with $\mathrm{Hg}^{2+}$. In other words, the $\mathrm{T}_{7}-\mathrm{MB}-\mathrm{T}_{7}$ forms dsDNA complexes in the presence of $\mathrm{Hg}^{2+}$ and $\mathrm{DNA}_{\mathrm{pm}}$, but a folded structure in the presence of $\mathrm{Hg}^{2+}$ and $\mathrm{DNA}_{\mathrm{mm}}$. As a result, the fluorescence of a solution containing $\mathrm{T}_{7}-\mathrm{MB}-\mathrm{T}_{7}, \mathrm{DNA}_{\mathrm{pm}}, \mathrm{EthBr}$, and $\mathrm{Hg}^{2+}$ is higher than that of a corresponding solution containing $\mathrm{T}_{7}-\mathrm{MB}$ $\mathrm{T}_{7}, \mathrm{DNA}_{\mathrm{mm}}$, EthBr, and $\mathrm{Hg}^{2+}$, mainly because the dsDNA complex formed in the former solution has a greater number of intercalation sites for EthBr.

We conducted proof-of-concept experiments using the $\mathrm{T}_{7}-\mathrm{MB}$ $\mathrm{T}_{7}$ probe and two different sequences of target DNA (Table 1): the perfectly matched DNA $\left(\mathrm{DNA}_{\mathrm{pm} 1}\right)$ and a single-base-mismatched DNA $\left(D_{N A} A_{m 1}\right)$. First, we prepared solutions consisting of the 

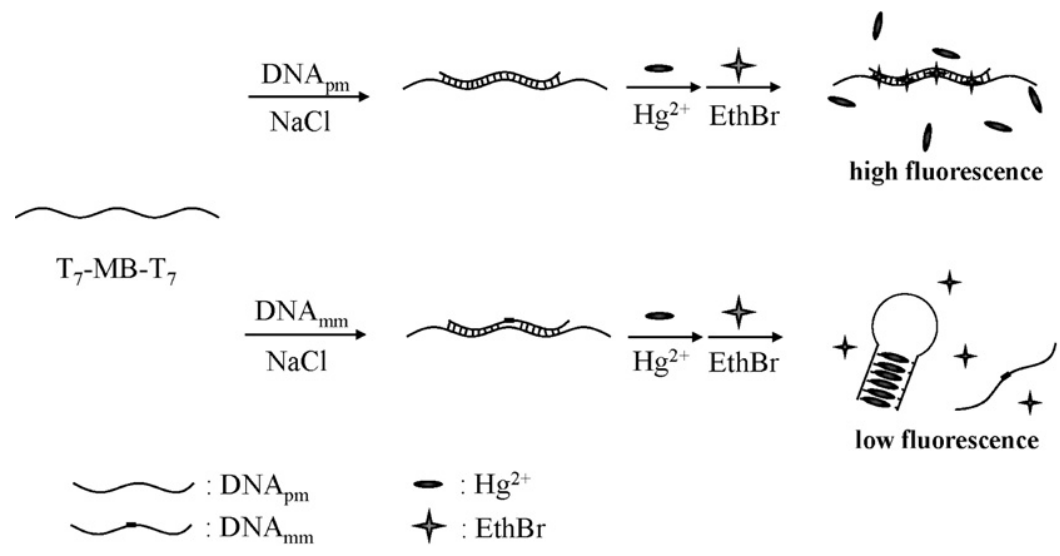

Scheme 1. Schematic representation of the mechanism of action of the $\mathrm{T}_{7}-\mathrm{MBs}$ probe for the detection of $\mathrm{DNA} \mathrm{pm}_{\mathrm{pm}}$ and $\mathrm{DAm}_{\mathrm{mm}}$ in the presence of $\mathrm{Hg}{ }^{2+}$ and $\mathrm{EthBr}$.

$\mathrm{T}_{7}-\mathrm{MB}-\mathrm{T}_{7}(100.0 \mathrm{nM})$, Tris-HCl (5.0 mM; pH 7.4), NaCl (20.0 mM), $\mathrm{Hg}^{2+}(5.0 \mu \mathrm{M})$, and $\mathrm{EthBr}(300.0 \mathrm{nM})$ in the absence and presence of $\mathrm{DNA}_{\mathrm{pm} 1}(100 \mathrm{nM})$. In the absence of $\mathrm{DNA}_{\mathrm{pm} 1}$, the fluorescence intensity of EthBr at $605 \mathrm{~nm}$ (excited at $520 \mathrm{~nm}$ ) was low (spectrum a, Fig. 1). In the presence of $\mathrm{DNA}_{\mathrm{pm} 1}$, the fluorescence intensity (spectrum b) of EthBr was much higher than that in the absence of the target DNA. These results support the sensing mechanism outlined in Scheme 1. In contrast, in the presence of $\mathrm{DNA}_{\mathrm{mm} 1}$, the fluorescence intensity of EthBr (spectrum c) in the $\mathrm{T}_{7}-\mathrm{MB}-\mathrm{T}_{7}$ probe solution increased only slightly, showing high specificity of the $\mathrm{T}_{7}-\mathrm{MB}-\mathrm{T}_{7}$ probe toward its target DNA. As a reference, we did not observe any difference in the fluorescence spectrum of an EthBr $(300.0 \mathrm{nM})$ solution lacking the $\mathrm{T}_{7}-\mathrm{MB}-\mathrm{T}_{7}$ after the addition of either $\mathrm{DNA}_{\mathrm{pm} 1}$ or $\mathrm{DNA}_{\mathrm{mm} 1}$. We note that EthBr intercalates much more strongly with dsDNA (or folded DNA) than it does with ssDNA.

\subsection{Optimal conditions}

The sensing capability of our $\mathrm{T}_{7}-\mathrm{MB}-\mathrm{T}_{7}$ probe toward DNA depends on the relative strength of the complexes of the $\mathrm{T}_{7}-\mathrm{MB}-$ $\mathrm{T}_{7}$ stem with $\mathrm{Hg}^{2+}$ and of its loop region with targeted DNA strands. Because the stability of the folded structure of $\mathrm{T}_{7}-\mathrm{MB}-\mathrm{T}_{7}$ with $\mathrm{Hg}^{2+}$ is dependent on the $\mathrm{Hg}^{2+}$ concentration, we expected that the concentration of $\mathrm{Hg}^{2+}$ would play a role in determining the specificity and sensitivity of our $\mathrm{T}_{7}-\mathrm{MB}-\mathrm{T}_{7}$ probe. We investigated (Fig. $2 \mathrm{~A}$ )

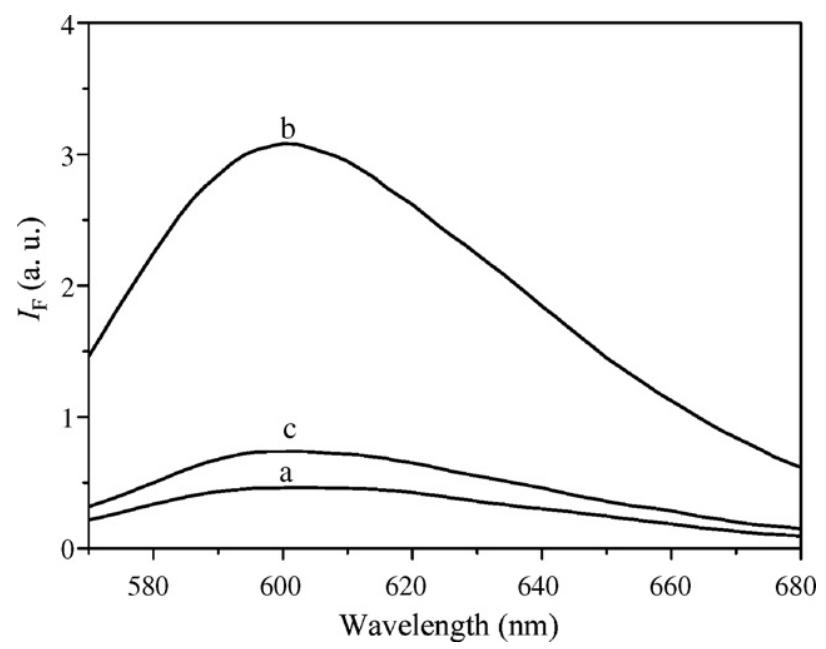

Fig. 1. Fluorescence spectra of $T_{7}-M B-T_{7}(100.0 \mathrm{nM})$ in the (a) absence of target DNA and $\left(b\right.$ and c) presence of (b) DNA $\mathrm{Dm}_{1}(100.0 \mathrm{nM})$ and $(\mathrm{c}) \mathrm{DNA}_{\mathrm{mm} 1}(100.0 \mathrm{nM})$ in 5.0 mM Tris- $\mathrm{HCl}(\mathrm{pH} 7.4)$ containing $20.0 \mathrm{mM} \mathrm{NaCl}, 5.0 \mu \mathrm{M} \mathrm{Hg}^{2+}$, and $300.0 \mathrm{nM} \mathrm{EthBr}$. the effect of $\mathrm{Hg}^{2+}$ at various concentrations $(0-10 \mu \mathrm{M})$ on the value of $\left(I_{\mathrm{F}}-I_{\mathrm{F} 0}\right) / I_{\mathrm{F} 0}$ of $\operatorname{EthBr}(1.0 \mu \mathrm{M})$ in the presence of DNA molecules and $\mathrm{T}_{7}-\mathrm{MB}-\mathrm{T}_{7}(100 \mathrm{nM})$, where $I_{\mathrm{F} 0}$ and $I_{\mathrm{F}}$ are the fluorescence intensities of the complexes of EthBr with $\mathrm{T}_{7}-\mathrm{MB}-\mathrm{T}_{7}$ in the absence and presence of the targeted DNA, respectively. Upon increasing the $\mathrm{Hg}^{2+}$ concentration, the fluorescence intensity decreased, suggesting that the hairpin DNA structure was more stable in the presence of higher concentrations of $\mathrm{Hg}^{2+}$. As a control, we used a traditional DNA-MB $\left(\mathrm{MB}_{\mathrm{C} 1}\right)$ to detect the target DNA under the same experimental conditions. $\mathrm{MB}_{\mathrm{C} 1}$ exhibited a high fluorescence background and, thus, its fluorescence enhancement upon binding the targeted DNA was relatively low (Figure S1, Supporting Information). When compared with the fluorescence behavior of the $\mathrm{T}_{7}-\mathrm{MB}-\mathrm{T}_{7}$ probe solution in the presence of $\mathrm{Hg}^{2+}$, the higher fluorescent background in the $\mathrm{MB}_{\mathrm{C} 1}$ system arose because more EthBr molecules intercalated with $\mathrm{MB}_{\mathrm{C} 1}$ in the stem region. We note that $\mathrm{Hg}^{2+}$ competes with EthBr to interact with DNA. The curves in Fig. $2 \mathrm{~A}$ also suggest that the concentration of $\mathrm{Hg}^{2+}$ is an important factor determining the specificity of the $\mathrm{T}_{7}-\mathrm{MB}-\mathrm{T}_{7}$. To determine the optimal $\mathrm{Hg}^{2+}$ concentration under the tested conditions, we plotted $\left(I_{\mathrm{F} 1}-I_{\mathrm{F} 0}\right) /\left(I_{\mathrm{F} 2}-I_{\mathrm{F} 0}\right)$ against the $\mathrm{Hg}^{2+}$ concentration, where $I_{\mathrm{F} 0}$, $I_{\mathrm{F} 1}$, and $I_{\mathrm{F} 2}$ are the fluorescence intensities of the solutions in the absence of targeted DNA, the presence of $\mathrm{DNA}_{\mathrm{pm} 1}$, and the presence of $D N A_{m m 1}$, respectively. A higher value of this ratio indicates a greater specificity of the $T_{7}-M B-T_{7}$ probe toward $D N A_{p m 1}$ over $\mathrm{DNA}_{\mathrm{mm} 1}$. The curve (open circles) in Fig. 2A displays that the value of $\left(I_{\mathrm{F} 1}-I_{\mathrm{F} 0}\right) /\left(I_{\mathrm{F} 2}-I_{\mathrm{F} 0}\right)$ reached a maximum at a $\mathrm{Hg}^{2+}$ concentration of $5.0 \mu \mathrm{M}$. At higher concentrations (e.g., $7.5 \mu \mathrm{M}$ ), the interactions of $\mathrm{T}_{7}-\mathrm{MB}-\mathrm{T}_{7}$ with $\mathrm{Hg}^{2+}$ are stronger than those with the target DNA, thereby reducing its ability to recognize the target DNA.

Next, we investigated the impact of the $\mathrm{pH}$ and the concentration of $\mathrm{NaCl}$ on the performance of our $\mathrm{T}_{7}-\mathrm{MB}-\mathrm{T}_{7}$ probe toward $\mathrm{DNA}_{\mathrm{pm} 1}$. Fig. $2 \mathrm{~B}$ suggests that the value of $\left(I_{\mathrm{F}}-I_{\mathrm{FO}}\right) / I_{\mathrm{F} 0}-$ and, hence, the specificity of the $\mathrm{T}_{7}-\mathrm{MB}-\mathrm{T}_{7}$ probe toward $\mathrm{DNA}_{\mathrm{pm}}$ over $\mathrm{DNA}_{\mathrm{mm} 1}-$ was optimal at $\mathrm{pH} 7.4$, mainly because $\mathrm{T}-\mathrm{Hg}^{2+}-\mathrm{T}$ bonding occurs preferably at pH 6.0-8.0 (Miyake et al., 2006). We note that $\mathrm{Hg}^{2+}$ binds directly to $\mathrm{N} 3$ of the $\mathrm{T}$ moiety and bridges two $\mathrm{T}$ residues to form a $\mathrm{T}-\mathrm{Hg}^{2+}-\mathrm{T}$ pair. Upon increasing the concentration of $\mathrm{NaCl}$ from 0 to $50 \mathrm{mM}$, the efficiency of hybridization increased and, thus, the value of $\left(I_{\mathrm{F}}-I_{\mathrm{FO}}\right) / I_{\mathrm{FO}}$ increased (Figure S2). Further increases in the $\mathrm{NaCl}$ concentration $\left(>50 \mathrm{mM}\right.$ ) led to the efficiency of the $\mathrm{T}_{7}-\mathrm{MB}-\mathrm{T}_{7}$ probe decreasing as a result of salt screening. From the curve of $\left(I_{\mathrm{F}}-I_{\mathrm{F} 0}\right) / I_{\mathrm{F} 0}$ plotted against the $\mathrm{NaCl}$ concentration, we determined that the optimal $\mathrm{NaCl}$ concentration was $20 \mathrm{mM}$ (Figure S2, Supporting Information).

We also compared the performance of $\mathrm{EthBr}$ with some other DNA-binding dyes, namely TOTO-3, YOYO-3, and OliGreen (OG), for the determination of target DNA molecules using the $\mathrm{T}_{7}-\mathrm{MB}-\mathrm{T}_{7}$ 

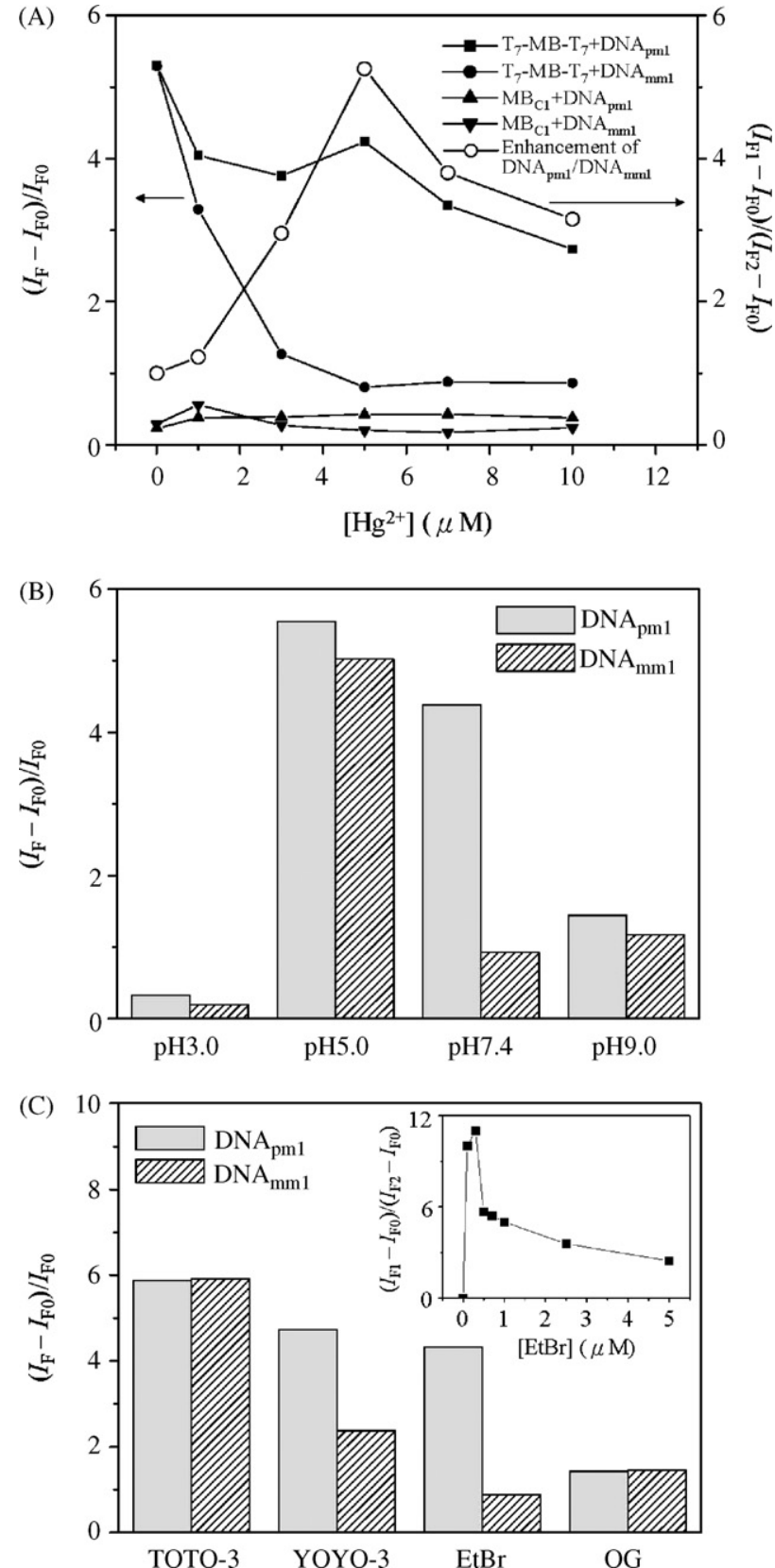

Fig. 2. (A) Plots of the values of $\left(I_{\mathrm{F}}-I_{\mathrm{FO}}\right) / I_{\mathrm{FO}}$, with respect to the concentration of $\mathrm{Hg}^{2+}$, of $\mathrm{T}_{7}-\mathrm{MB}-\mathrm{T}_{7}$ and $\mathrm{MB}_{\mathrm{C} 1}$ solutions containing $\operatorname{EthBr}(1.0 \mu \mathrm{M})$ in the presence of $\mathrm{DNA}_{\mathrm{pm} 1}$ $(100 \mathrm{nM})$ or DNA $\mathrm{mm}_{\mathrm{m} 1}(100 \mathrm{nM})$ and of $\left(I_{\mathrm{F} 1}-I_{\mathrm{F} 0}\right) /\left(I_{\mathrm{F} 2}-I_{\mathrm{F} 0}\right)$ of $\mathrm{T}_{7}-\mathrm{MB}-\mathrm{T}_{7}$ probe solutions $(100 \mathrm{nM})$ containing EthBr in the presence of DNA $\mathrm{pm}_{\mathrm{m}}\left(I_{\mathrm{F} 1}\right)$ or $\mathrm{DNA}_{\mathrm{mm} 1}\left(I_{\mathrm{F} 2}\right) . I_{\mathrm{F} 0}$ and $I_{\mathrm{F}}$ are the fluorescence intensities of the solutions in the absence and presence of the targeted DNA, respectively. (B) Values of $\left(I_{\mathrm{F}}-I_{\mathrm{F} 0}\right) / I_{\mathrm{F} 0}$ of $\mathrm{T}_{7}-\mathrm{MB}-\mathrm{T}_{7}$ in the presence of either $\mathrm{DNA}_{\mathrm{pm} 1}$ or $\mathrm{DNA}_{\mathrm{mm} 1}$ plotted with respect to the $\mathrm{pH}$. (C) Plots of the values of $\left(I_{\mathrm{F}}-I_{\mathrm{F} 0}\right) / I_{\mathrm{F} 0}$ of $\mathrm{T}_{7}-\mathrm{MB}-\mathrm{T}_{7}$ solutions containing various fluorophores $(1.0 \mu \mathrm{M})$ in the presence of $\mathrm{DNA}_{\mathrm{pm} 1}$ or $\mathrm{DNA} \mathrm{Amm}_{\mathrm{m} 1}$. Inset: plot of the values of $\left(I_{\mathrm{F} 1}-I_{\mathrm{FO}}\right) /\left(I_{\mathrm{F} 2}-I_{\mathrm{FO}}\right)$ for $\mathrm{T}_{7}-\mathrm{MB}-\mathrm{T}_{7}$ in the presence of $\mathrm{DNA} \mathrm{pm}_{\mathrm{pm} 1}$ and $\mathrm{DNA}_{\mathrm{mm} 1}$ with respect to the concentration of $\operatorname{EthBr}(0-5.0 \mu \mathrm{M})$.

probe. Of these dyes, the specificity of the $\mathrm{T}_{7}-\mathrm{MB}-\mathrm{T}_{7}$ probe toward $\mathrm{DNA}_{\mathrm{pm}}$ over DNA $\mathrm{Am}_{\mathrm{mm}}$ was best when using EthBr (Fig. 2C). We note that both TOTO-3 and YOYO-3 bind to DNA with greater affinity $\left(K_{\mathrm{a}}=\right.$ ca. $10^{9}$ and ca. $10^{7} \mathrm{M}^{-1}$, respectively) than does $\operatorname{EthBr}\left(K_{\mathrm{a}}=\right.$ ca. $10^{6} \mathrm{M}^{-1}$ ) (Bowen and Woodbury, 2003; Mecklenburg et al., 1997; Joseph et al., 1996).

The lower specificity of the $\mathrm{T}_{7}-\mathrm{MB}-\mathrm{T}_{7}$ probe toward $\mathrm{DNA}_{\mathrm{pm}}$ over $\mathrm{DNA}_{\mathrm{mm}}$ when using the higher-affinity intercalating dyes suggests that stronger intercalators stabilize the hybridization of $\mathrm{T}_{7}-\mathrm{MB}-\mathrm{T}_{7}$

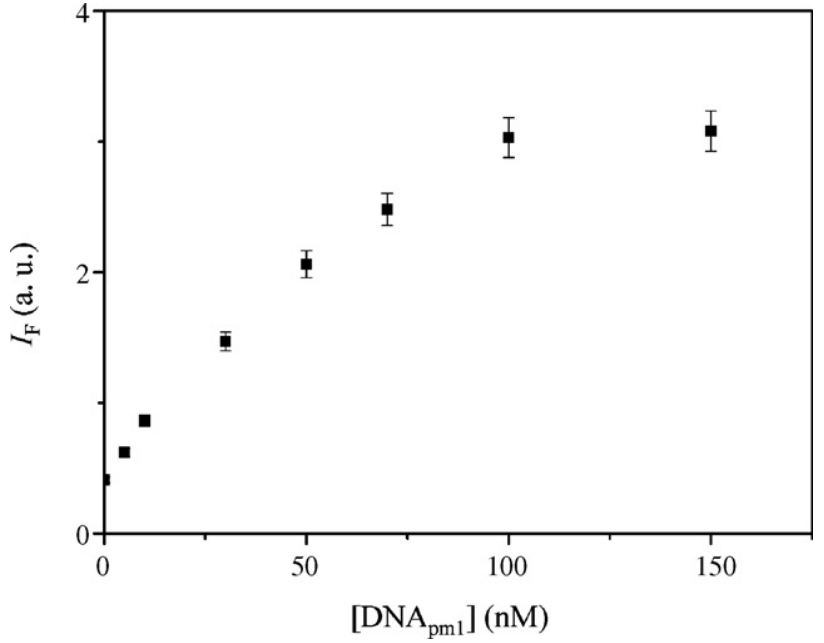

Fig. 3. Fluorescence intensity of EthBr at $605 \mathrm{~nm}$ in $\mathrm{T}_{7}-\mathrm{MB}-\mathrm{T}_{7}$ probe solutions plotted with respect to the $\mathrm{DNA}_{\mathrm{pm} 1}$ concentration. 10 measurements were conducted at each $\mathrm{DNA}_{\mathrm{pm} 1}$ concentration. Other conditions were the same as those described in Fig. 1.

with its targeted DNA and, therefore, decrease the specificity of the $\mathrm{T}_{7}-\mathrm{MB}-\mathrm{T}_{7}$ probe (Boger et al., 2001; Wang et al., 2005; Chen et al., 2008). We further investigated the effect of the EthBr concentration on the specificity of the $\mathrm{T}_{7}-\mathrm{MB}-\mathrm{T}_{7}$ probe. The fluorescence intensities of the solutions increased (spectra not shown) upon increasing the EthBr concentration either in the absence or in the presence of its targeted DNA. The inset to Fig. 2C indicates that the specificity of $\mathrm{T}_{7}-\mathrm{MB}-\mathrm{T}_{7}$ reached a maximum at $300.0 \mathrm{nM}$ EthBr. At higher EthBr concentrations, fluorescence background was greater; poor specificity occurred, mainly because greater numbers of intercalated EthBr molecules further stabilized the hybridization of $\mathrm{T}_{7}-\mathrm{MB}-\mathrm{T}_{7}$ with $\mathrm{DNA}_{\mathrm{pm}}$ or with $\mathrm{DNA}_{\mathrm{mm}}$; the use of too much carcinogenic EthBr might also be problematic from a practical point of view. Thus, the $\mathrm{T}_{7}-\mathrm{MB}-\mathrm{T}_{7}$ probe providing optimal specificity comprised $100.0 \mathrm{nM} \mathrm{T}_{7}-\mathrm{MB}-\mathrm{T}_{7}$ in $5.0 \mathrm{mM}$ Tris- $\mathrm{HCl}$ solution ( $\mathrm{pH} 7.4$ ) containing $5.0 \mu \mathrm{M} \mathrm{Hg}^{2+}$, $20.0 \mathrm{mM} \mathrm{NaCl}$, and 300.0 nM EthBr.

\subsection{Sensitivity and specificity}

Under the optimal conditions, we investigated the sensitivity of the $\mathrm{T}_{7}-\mathrm{MB}-\mathrm{T}_{7}$ probe toward $\mathrm{DNA}_{\mathrm{pm}}$. We obtained a linear response of the fluorescence intensity with respect to the concentration of $\mathrm{DNA}_{\mathrm{pm}}$ (Fig. 3) over the range $5.0-100 \mathrm{nM}\left(R^{2}=0.98\right)$. Then, we calculated the limit of detection (LOD) using the equation, $\mathrm{S}_{\mathrm{m}}=\mathrm{S}_{\mathrm{b} 1}+k \mathrm{~s}_{\mathrm{bl}}$, in which $\mathrm{S}_{\mathrm{b} 1}$ is the average blank (10 measurements) and $s_{b l}$ is the standard deviation of the blank. The values of $s_{b 1}$ and $s_{b l}$ were 41 and 1.4 , respectively. We then calculated $S_{m}$ to be 45.2 , based on 3-times of $s_{\mathrm{bl}}(k=3)$. Finally, we obtained the LOD to be $1.0 \mathrm{nM}$ by using the linear equation $(y=4.42 \mathrm{x}+40.8)$. Fig. $4 \mathrm{~A}$ indicates that the selectivity of $\mathrm{T}_{7}-\mathrm{MB}-\mathrm{T}_{7}$ and $\mathrm{MB}_{\mathrm{C} 2}$ toward $\mathrm{DNA}_{\mathrm{pm} 1}$ over $\mathrm{DNA}_{\mathrm{mm} 1}$ at ambient temperature were 9.8- and 1.3-fold, respectively. When conducting the assay at $35^{\circ} \mathrm{C}$ (optimal conditions), the selectivity of $\mathrm{MB}_{\mathrm{C} 2}$ toward $\mathrm{DNA}_{\mathrm{pm} 1}$ over $\mathrm{DNA} \mathrm{Amm}_{\mathrm{mm}}$ was 3.6-fold. We also modified the fluorophores (FAM and DABCYL) on the two termini of $\mathrm{MB}_{\mathrm{C} 3-6}$ (Table 1 ) to compare the performance of the standard MBs with $\mathrm{T}_{7}-\mathrm{MB}-\mathrm{T}_{7}$ in SNPs study. We changed the concentrations of $\mathrm{NaCl}(5-100 \mathrm{mM})$ and temperatures $\left(25-75^{\circ} \mathrm{C}\right)$ to obtain the optimal conditions for these standard beacons. Because the $T_{m}$ values of $\mathrm{MB}_{\mathrm{C} 3}$ and $\mathrm{MB}_{\mathrm{C} 5}$ (the contents of $\mathrm{GC}$ pairs in the stem are 0 and $29 \%$, respectively) are both lower than $10^{\circ} \mathrm{C}$, there is thus no need to conduct the sensing at higher temperature. The optimum conditions for $\mathrm{MB}_{\mathrm{C} 4}$ and $\mathrm{MB}_{\mathrm{C} 6}$ (GC pairs in stem: 100 and $86 \%$, respectively) were 80 and $50 \mathrm{mM} \mathrm{NaCl}$ at 55 and 

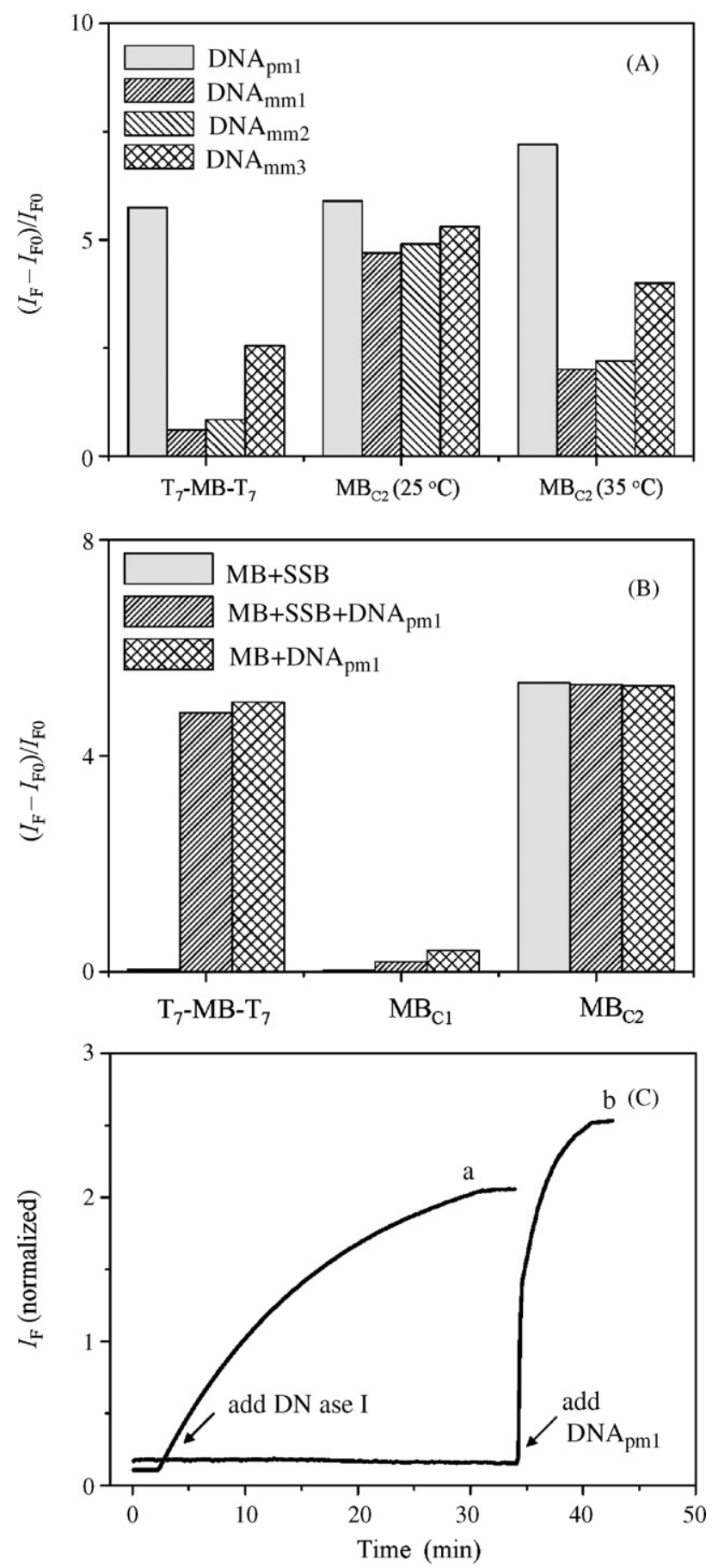

Fig. 4. (A) Fluorescence enhancements of $T_{7}-M B-T_{7}$ probe solutions containing EthBr and $\mathrm{MB}_{\mathrm{C} 2}$ in the presence of $\mathrm{DNA}_{\mathrm{pm} 1}, \mathrm{DNA}_{\mathrm{mm} 1}, \mathrm{DNA}_{\mathrm{mm} 2}$, and $\mathrm{DNA}_{\mathrm{mm} 3}$ $(100.0 \mathrm{nM})$ at ambient temperature and $35^{\circ} \mathrm{C}$, respectively. (B) Fluorescence responses of $\mathrm{T}_{7}-\mathrm{MB}-\mathrm{T}_{7}, \mathrm{MB}_{\mathrm{C} 1}$, and $\mathrm{MB}_{\mathrm{C} 2}(100.0 \mathrm{nM})$ solutions containing EthBr in the presence and absence of SSB (100.0 nM). (C) Resistance to DNase I $(2.5 \mu \mathrm{g} / \mathrm{mL})-$ mediated digestion of (a) $\mathrm{MB}_{\mathrm{C} 2}$ and (b) $\mathrm{T}_{7}-\mathrm{MB}-\mathrm{T}_{7}(100 \mathrm{nM})$ in the presence of $\mathrm{Hg}^{2+}$ and $5.0 \mathrm{mM} \mathrm{MgCl}_{2}$. Other conditions were the same as those described in Fig. 1.

$50^{\circ} \mathrm{C}$, respectively. Their selectivity values were 2.8 and 4.1 , respectively. These results indicated the selectivity of the standard MBs was highly dependent on the DNA sequences and temperature. When compared to those of the standard MBs, the selectivity of $\mathrm{T}_{7}-\mathrm{MB}-\mathrm{T}_{7}$ was less dependent on temperature, mainly because the $\mathrm{T}-\mathrm{Hg}^{2+}-\mathrm{T}$ complex was more stable than the double stranded DNA at high temperature. We further tested our probe toward other target DNAs ( $\mathrm{DNA}_{\mathrm{mm} 4-9}$; Table 1 ) that have different mismatched sequences. The selectivity values of $\mathrm{T}_{7}-\mathrm{MB}-\mathrm{T}_{7}$ toward $\mathrm{DNA} \mathrm{A}_{\mathrm{pm} 1}$ over $\mathrm{DNA}_{\text {mm4-9 }}$ at ambient temperature were $4.5,4.9,4.2,8.4,5.9$, and 14.8 , respectively. Because $\mathrm{Hg}^{2+}$ and $\mathrm{EthBr}$ both interacted with the single stranded DNA and doubled stranded DNA (DNA probe and target DNA), they played some roles in determining the selectivity of our probe. When compared to the normal MBs, the $\mathrm{T}_{7}-\mathrm{MB}-\mathrm{T}_{7}$ is advantageous; without conducting the assay at high temperature. We compared the resistance of $\mathrm{T}_{7}-\mathrm{MB}-\mathrm{T}_{7}$ and the conventional $\mathrm{MBs}\left(\mathrm{MB}_{\mathrm{C} 1}\right.$ and $\left.\mathrm{MB}_{\mathrm{C} 2}\right)$ to interactions with the nonspecific binding protein SSB. The presence of SSB did not cause significant changes in the fluorescence intensities of EthBr in solutions containing $\mathrm{MB}_{\mathrm{C} 1}$ in the presence or absence of $\mathrm{DNA}_{\mathrm{pm} 1}$, suggesting that no interactions occur between $\mathrm{MB}_{\mathrm{C} 1}$ and $\mathrm{DNA}_{\mathrm{pm} 1}$ in the presence of SSB. In contrast, SSB caused increases in the fluorescence intensity of $\mathrm{MB}_{\mathrm{C} 2}$ in the presence and absence of $\mathrm{DNA}_{\mathrm{pm} 1}$, mainly because $\mathrm{MB}_{\mathrm{C} 2}$ forms a random coiled structure upon its interaction with SSB (Leonetti et al., 1991; Fisher et al., 1993), leading to the false-positive signal in Fig. 4B. In contrast, the $\mathrm{T}_{7}-\mathrm{MB}-\mathrm{T}_{7}$ did not respond to the addition of excess SSB, but the value of $\left(I_{\mathrm{F}}-I_{\mathrm{FO}}\right) / I_{\mathrm{F} 0}$ increased once $\mathrm{DNA}_{\text {pm }}$ was added, indicating that our probe should be superior to conventional MBs for the detection of its target DNA in biological samples. We also compared the stabilities of the $T_{7}-M B-T_{7}$ and conventional $\mathrm{MB}$ probes in the presence of DNase I. Whereas $\mathrm{MB}_{\mathrm{C} 2}$ degraded rapidly once DNase I was added (curve a, Fig. 4C), the $\mathrm{T}_{7}-\mathrm{MB}-\mathrm{T}_{7}$ degraded only slightly during the first $30 \mathrm{~min}$ (curve $\mathrm{b}$ ), mainly because of the greater stability of folded DNA relative to that of ssDNA (Kim et al., 2007). Nevertheless, the use of toxic $\mathrm{Hg}^{2+}$ ions, albeit in small amounts, in our probe system is a disadvantageous feature. This disadvantage can be overcome by using different DNA sequences that respond to the presence of lower toxicity metal ions such as $\mathrm{Ag}^{+}, \mathrm{Cu}^{2+}$, and $\mathrm{K}^{+}$ions (Ono and Miyake, 2001; Meggers et al., 2000; Huang and Chang, 2008). Furthermore, we also believe that this approach can serve as a foundation for the development of practical DNA chip for high throughput SNPs screen.

We further tested the impacts that the DNA sequences in the MBs have on SNPs study. To study the impact of the length of stem (number of thymidine) on SNPs study, $\mathrm{T}_{6}-\mathrm{MB}-\mathrm{T}_{6}$ and $\mathrm{T}_{8}-\mathrm{MB}-\mathrm{T}_{8}$ were tested. The optimal concentrations of $\mathrm{Hg}^{2+}$ for $\mathrm{T}_{6}-\mathrm{MB}-\mathrm{T}_{6}$ and $\mathrm{T}_{8^{-}}$ $\mathrm{MB} \mathrm{T}_{8}$ were 3.0 and $7.0 \mu \mathrm{M}$, respectively (Figure $\mathrm{S} 3 \mathrm{~A}$ ). The LODs and specificities of $\mathrm{T}_{8}-\mathrm{MB}-\mathrm{T}_{8}$ for the targeted DNA $\left(\mathrm{DNA}_{\mathrm{pm} 1}\right.$, Table 1) were close to those of $\mathrm{T}_{7}-\mathrm{MB}-\mathrm{T}_{7}$, which were better than those of $\mathrm{T}_{6}-\mathrm{MB}-\mathrm{T}_{6}$ for the targeted DNA $\left(\mathrm{DNA}_{\mathrm{pm} 1}\right)$. When thymidine chain in the stem was too short, the stability of hairpin structure is too weak to compete with the hybridization of the probe to the target DNA. On the other hand, when the chain length is too long, it is difficult for the hybridization of the probe with the target DNA to occur. We also discussed the impact of GC contents in the stems on the specificity of our approach toward target DNA. The percentages of GC pairs in the stems of $\mathrm{MB}_{\mathrm{C} 1}, \mathrm{MB}_{\mathrm{C} 3}, \mathrm{MB}_{\mathrm{C} 4}, \mathrm{MB}_{\mathrm{C} 5}$, and $\mathrm{MB}_{\mathrm{C} 6}$ were 57,0 , 100,29 , and $86 \%$. The selectivity values for these five probes toward the perfect match DNAs $\left(\mathrm{DNA}_{\mathrm{pm} 1}\right)$ over mismatch DNAs $\left(\mathrm{DNA}_{\mathrm{mm} 1}\right)$ were $2.4,2.3,1.9,2.4$, and 2.1 , respectively, all providing poor selectivity when compared to the thymidine-based MBs. Next, we kept the stem as the same $\left(T_{7}\right)$, but changed the GC contents in the loop of $\mathrm{MBs}\left(\mathrm{T}_{7}-\mathrm{MB}_{1}-\mathrm{T}_{7}\right.$ and $\left.\mathrm{T}_{7}-\mathrm{MB}_{2}-\mathrm{T}_{7}\right)$. We point out that the percentages of GC pairs in the loops of $\mathrm{T}_{7}-\mathrm{MB}-\mathrm{T}_{7}, \mathrm{~T}_{7}-\mathrm{MB}_{1}-\mathrm{T}_{7}$, andT $\mathrm{T}_{7}-\mathrm{MB}_{2}-\mathrm{T}_{7}$ were 42,21 , and $63 \%$, respectively. We observed that the specificity and sensitivity for the target DNA are also dependent on the contents of GC pairs in the loop of the MBs (Figure S3B). The optimal concentrations of $\mathrm{Hg}^{2+}$ with respects to the specificity and sensitivity of the $T_{7}-M B-T_{7}, T_{7}-M B_{1}-T_{7}$ and $T_{7}-M B_{2}-T_{7}$ for the $D_{N A}$ were 5.0, 1.0 and $20 \mu \mathrm{M} \mathrm{Hg}^{2+}$, respectively. The results suggest that higher concentrations of $\mathrm{Hg}^{2+}$ are required when the GC contents in the MBs are higher. The selectivity values for these three probes toward the perfect match DNAs $\left(\mathrm{DNA}_{\mathrm{pm} 1}, \mathrm{DNA}_{\mathrm{pm} 2}\right.$, and $\left.\mathrm{DNA}_{\mathrm{pm} 3}\right)$ over mismatch DNAs $\left(\mathrm{DNA}_{\mathrm{mm} 1}, \mathrm{DNA}_{\mathrm{mm} 10}\right.$, and $\left.\mathrm{DNA}_{\mathrm{mm} 11}\right)$ were 9.8, 
4.4, and 8.2 and LODs for the perfect match DNAs were 1.0, 3.5, and 2.1, respectively. Our results suggest that in our MBs the length of stem plays more important roles than that of the sequence in the loop in determining their specificity and sensitivity for DNA. We also suggest that MBs having high GC contents are not proper from the view point of safety because greater amounts of $\mathrm{Hg}^{2+}$ are required.

To test the practicality, we used another DNA probe $\left(\mathrm{T}_{7}-\mathrm{MB}_{t^{-}}\right.$ $\mathrm{T}_{7}$ ) that can recognize the fumarylacetoacetate hydrolase (FAH) gene. Mutation of this gene is associated with a human genetic disease, hereditary tyrosinemia type I (St-Louis and Tanguay, 1997; Phaneuf et al., 1992). The sequence of the new probe $\mathrm{T}_{7}-\mathrm{MB}_{\mathrm{t}}-$ $\mathrm{T}_{7}$ is complementary to the wild type of this gene (DNA $\mathrm{Dmt}_{\mathrm{p}}$ : 5 '-CCGGTGAGTATCTGG-3'). Figure $S 4$ reveals that our probe is sensitive to this gene, with an LOD of $1.0 \mathrm{nM}$. Like $\mathrm{T}_{7}-\mathrm{MB}-\mathrm{T}_{7}$, the $\mathrm{T}_{7}-\mathrm{MB}_{\mathrm{t}}-\mathrm{T}_{7}$ is resistant to nonspecific interactions with SSB and stable in the presence of DNase I. We tested the selectivity of our $\mathrm{T}_{7}-\mathrm{MB}_{\mathrm{t}}-\mathrm{T}_{7}$ probe by measuring its affinity toward a mutated DNA (DNA mmt $_{\text {t }}$ 5'-CCGGTGAATATCTGG-3'). The inset to Figure S4 displays that the selectivity of our probe toward $D N A_{\text {pmt }}$ over $D N A_{m m t}$ was greater than 4.0 -fold.

\section{Conclusion}

We have developed a simple, cost-effective, sensitive, and selective assay-using $\mathrm{T}_{7}-\mathrm{MB}-\mathrm{T}_{7}$ and $\mathrm{T}_{7}-\mathrm{MB}_{\mathrm{t}}-\mathrm{T}_{7}$ probes in the presence of $\mathrm{Hg}^{2+}$ and EthBr-for studying SNPs. The sensing specificity is dependent on a competition between the target DNA strand and $\mathrm{Hg}^{2+}$ ions for interaction with the $\mathrm{T}_{7}-\mathrm{MB}-\mathrm{T}_{7}$. We have demonstrated that the $\mathrm{T}_{7}-\mathrm{MB}_{\mathrm{t}}-\mathrm{T}_{7}$ is sensitive and selective, with an LOD of $1.0 \mathrm{nM}$, for the detection of a gene associated with hereditary tyrosinemia type I. Unlike conventional approaches, there is no need to use fluorescently labeled MBs in our system. In addition, the $\mathrm{T}_{7}$-MBs probes are much more resistant to nonspecific binding with SSB and to nuclease digestion. We envision that $\mathrm{T}_{7}-\mathrm{MB}$ probes will be useful for practical studies of SNPs.

\section{Acknowledgments}

This study was supported by the National Science Council of Taiwan under contracts NSC-95-2113-M-002-026-MY3, NSC 97-2627-M-002-010 and NSC 97-2627-M-002-011. Y.-W.L. thanks National Taiwan University for PDF support (96R0066-37).

\section{Appendix A. Supplementary data}

Supplementary data associated with this article can be found, in the online version, at doi:10.1016/j.bios.2009.01.003.

\section{References}

Boger, D.L., Fink, B.E., Brunette, S.R., Tse, W.C., Hedrick, M.P., 2001. J. Am. Chem. Soc 123, 5878-5891.

Bowen, B.P., Woodbury, N.W., 2003. Photochem. Photobiol. 78 (6), 582-586.

Chen, S.-J., Huang, Y.-F., Huang, C.-C., Lee, K.-H., Lin, Z.-H., Chang, H.-T., 2008. Biosens. Bioelectron. 23, 1749-1753.

Drummond, T.G., Hill, M.G., Barton, J.K., 2003. Nat. Biotechnol. 21 (10), 1192-1199.

Fisher, T.L., Terhorst, T., Cao, X., Wagner, R.W., 1993. Nucleic Acids Res. 21 (16) 3857-3865.

Gaylord, B.S., Heeger, A.J., Bazan, G.C., 2002. Proc. Natl. Acad. Sci. U. S. A 99 (17), 10954-10957.

Gray, I.C., Campbell, D.A., Spurr, N.K., 2000. Hum. Mol. Genet. 9 (16), 2403-2408.

Huang, C.-C., Chang, H.-T., 2008. Chem. Commun., 1461-1463.

Joseph, M.J., Taylor, J.C., McGown, L.B., Pitner, J.B., Linn, C.P., 1996. Biospectroscopy 2, $173-183$.

Kelley, S.O., Boon, E.M., Barton, J.K., Jackson, N.M., Hill, M.G., 1999. Nucleic Acids Res 27 (24), 4830-4837.

Kim, Y., Yang, C.J., Tan, W., 2007. Nucleic Acids Res. 35 (21), 7279-7287.

Kuhn, H., Demidov, V.V., Coull, J.M., Fiandaca, M.J., Gildea, B.D., Frank-Kamenetskii, M.D., 2002. J. Am. Chem. Soc. 124 (6), 1097-1103.

Kolpashchikov, D.M., 2008. J. Am. Chem. Soc. 130, 2934-2935.

Leonetti, J.P., Mechti, N., Degols, G., Gagnor, C., Lebleu, B., 1991. Proc. Natl. Acad. Sci. U. S. A 88, 2702-2706.

Li, J., Chu, X., Liu, Y., Jiang, J.H., He, Z., Zhang, Z., Shen, G., Yu, R.Q., 2005. Nucleic Acids Res. 33 (19), e168.

Lin, Y.-W., Ho, H.-T., Huang, C.-C., Chang, H.-T., 2008. Nucleic Acids Res. doi:10.1093/nar/gkn537.

Liu, B., Bazan, G.C., 2004. Chem. Mater. 16 (23), 4467-4476.

Liu, C.-W., Hsieh, Y.-T., Huang, C.-C., Chang, H.-T., 2008. Chem. Commun., 2242-2244.

Mecklenburg, M., Grauers, A., Jönsson, B.R., Weber, A., Danielsson, B., 1997. Anal. Chim. Acta 347, 79-86.

Meggers, E., Holland, P.L., Tolman, W.B., Romesberg, F.E., Schultz, P.G., 2000. J. Am. Chem. Soc. 122, 10714-10715.

Miyake, Y., Togashi, H., Tashiro, M., Yamaguchi, H., Oda, S., Kudo, M., Tanaka, Y., Kondo, Y., Sawa, R., Fujimoto, T., Machinami, T., Ono, A., 2006. J. Am. Chem. Soc. 128, 2172-2173.

Nam, J.M., Stoeva, S.I., Mirkin, C.A., 2004. J. Am. Chem. Soc. 126, 5932-5933.

Ono, A., Miyake, Y., 2001. Nucleic Acids Symp. Ser. 1, 227-228.

Ono, A., Togashi, H., 2004. Angew. Chem. Int. Ed. 43, 4300-4302.

Phaneuf, D., Lambert, M., Laframboise, R., Mitchell, G., Lettre, F., Tanguay, R.M., 1992. J. Clin. Invest. 90, 1185-1192.

St-Louis, M., Tanguay, R.M., 1997. Hum. Mutat. 9, 291-299.

Storhoff, J.J., Lucas, A.D., Garimella, V., Bao, Y.P., Müller, U.R., 2004. Nat. Biotechnol. 22 (7), 883-887.

Tsourkas, A., Behlke, M., Bao, G., 2002. Nucleic Acids Res. 30 (23), 5168-5174.

Tyagi, S., Kramer, F.R., 1996. Nat. Biotechnol. 14, 303-308.

Wang, J., Jiang, Y., Zhou, C., Fang, X., 2005. Anal. Chem. 77 (11), 3542-3546. 